\title{
Electron Transfer between Hydrogen-Bonded Pyridylphenols and a Photoexcited Rhenium(I) Complex
}

\author{
William Herzog, ${ }^{[b]}$ Catherine Bronner, ${ }^{[a]}$ Susanne Löffler, ${ }^{[c]}$ Bice He, ${ }^{[c]}$ Daniel \\ Kratzert, ${ }^{[c]}$ Dietmar Stalke, ${ }^{[c]}$ Andreas Hauser, ${ }^{[b]}$ and Oliver S. Wenger ${ }^{*[a]}$
}

Two pyridylphenols with intramolecular hydrogen bonds between the phenol and pyridine units were synthesized, characterized crystallographically, and investigated by cyclic voltammetry and UVvis spectroscopy. Reductive quenching of the ${ }^{3} \mathrm{MLCT}$ excited state of the $\left[\operatorname{Re}(\text { phen })(C O)_{3}(p y)\right]^{+}$complex (phen $=1,10$-phenanthroline, $p y=$ pyridine) by the two pyridylphenols and two reference phenol molecules was investigated by steady-state and time-resolved luminescence spectroscopy, as well as by transient absorption spectroscopy. Stern-Volmer analysis of the luminescence quenching data provides rate constants for the bimolecular excited-state quenching reactions. $H / D$ kinetic isotope effects (KIEs) for the pyridylphenols are on the order of 2.0, and the bimolecular quenching reactions are up to 100 times faster with the pyridylphenols than with the reference phenols. This observation is attributed to the markedly less positive oxidation potentials of the pyridylphenols with respect to the reference phenols (ca. $0.5 \mathrm{~V}$ ), which in turn is caused by protoncoupling of the phenol oxidation process. Transient absorption spectroscopy provides unambiguous evidence for the photogeneration of phenoxyl radicals, $i$. e., the overall photoreaction is clearly a PCET process

\section{Introduction}

The tyrosine Z ( $\mathrm{Tyr}_{\mathrm{z}}$ / / histidine 190 (His190) pair of photosystem II is one of the best-known hydrogen-bonded phenol systems in chemistry. ${ }^{[1]}$ Numerous experimental and theoretical investigations have been geared at understanding the protoncoupled electron transfer (PCET) chemistry of the Tyrz / His190 reaction couple, many of them focusing on simple artificial model compounds in which a phenol unit can form intramolecular hydrogen bonds to a nitrogen base. ${ }^{[2]} \mathrm{A}$ wide range of experimental methods has been applied, including EPR, ${ }^{[3]}$ electrochemical, ${ }^{[4]}$ and optical spectroscopic studies. ${ }^{[5]}$ However, in most cases the phenol oxidation process involves oxidants which are in their electronic ground states, and there are comparatively few studies in which the oxidant is an electronically excited molecule. ${ }^{[5 b, 6]}$

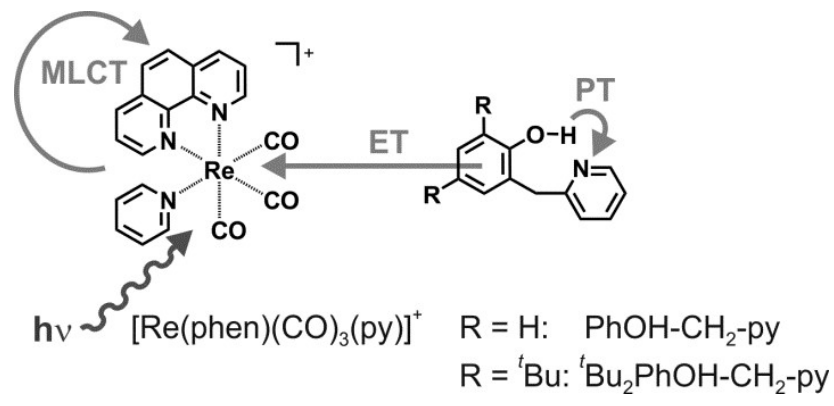

Scheme 1. Molecular structures of the photosensitizer/quencher pairs with the two hydrogen-bonded phenol molecules of central interest to this study; $h v=$ light excitation; MLCT = metal-to-ligand charge transfer excitation; $\mathrm{ET}=$ electron transfer; $\mathrm{PT}=$ proton transfer.

Against this background we deemed it interesting to explore the photoredox chemistry between hydrogen-bonded phenol molecules and a photoexcited rhenium(I) tricarbonyl dimine complex which is known to be a potent excited-state oxidant. ${ }^{[6 e, 7]}$ The molecular structures of our model systems are shown in Scheme 1. The rhenium(I) complex has a 1,10-phenanthroline (phen) and a pyridine (py) ligand in addition to the three carbonyls the phenol reaction partners have pendant pyridine units that are connected via a $-\mathrm{CH}_{2}$ - group in order to disrupt $\pi$-conjugation between the two aromatic subunits. One of the phenols contains no further substituents $\left(\mathrm{PhOH}-\mathrm{CH}_{2}-\mathrm{py}\right)$ while the other has tert.butyl groups at the 4- and 6-positions ( $\left.{ }^{\mathrm{B}} \mathrm{Bu}_{2} \mathrm{PhOH}-\mathrm{CH}_{2}-\mathrm{py}\right)$. We anticipated that when excited to its long-lived ${ }^{3} \mathrm{MLCT}$ state the rhenium(I) complex would be capable of inducing intermolecular electron transfer (ET) with the phenol, and this process should be accompanied by intramolecular proton transfer (PT) between the phenol and the pyridine.

The PCET chemistry of ${ }^{t} \mathrm{Bu}_{2} \mathrm{PhOH}-\mathrm{CH}_{2}$-py with various

[a] Dr. C. Bronner, Prof. O. S. Wenger

Departement für Chemie

Universität Basel

Spitalstrasse 51, CH-4056 Basel, Switzerland

Fax: +41(0)612670976

E-mail: oliver.wenger@unibas.ch

[b] Dr. W. Herzog, Prof. A. Hauser

Département de Chimie Physique

Université de Genève

30 quai Ernest-Ansermet, $\mathrm{CH}-1211$ Genève 4, Switzerland

[c] S. Löffler, Dr. B. He, D. Kratzert, Prof. D. Stalke

Institut für Anorganische Chemie

Georg-August Universität

Tammannstrasse 4, D-37077 Göttingen, Germany 
oxidants in their electronic ground states has been found previously to occur via a concerted proton-electron transfer (CPET) mechanism. ${ }^{[2 e, 5 c-f]}$ Here we focus specifically on the excited-state PCET chemistry between $\left[\operatorname{Re}(\text { phen })(\mathrm{CO})_{3}(\mathrm{py})\right]^{+}$and $\mathrm{PhOH}-\mathrm{CH}_{2}$-py or ${ }^{t} \mathrm{Bu}_{2} \mathrm{PhOH}-\mathrm{CH}_{2}$-py. As reference phenols without the possibility of forming intramolecular hydrogen bonds we used ordinary phenol $(\mathrm{PhOH})$ and 2,4-di-tert.-butylphenol $\left({ }^{t} \mathrm{Bu}_{2} \mathrm{PhOH}\right)$.

\section{Results and Discussion}

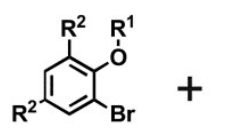

$1 \mathrm{R}^{1}=\mathrm{H}, \mathrm{R}^{2}=\mathrm{H}$

$2 \mathrm{R}^{1}=\mathrm{CH}_{3}, \mathrm{R}^{2}=\mathrm{H}$

$3 \mathrm{R}^{1}=\mathrm{H}, \mathrm{R}^{2}={ }^{t} \mathrm{Bu}$

$4 \mathrm{R}^{1}=\mathrm{CH}_{3}, \mathrm{R}^{2}={ }^{\mathrm{B}} \mathrm{Bu}$

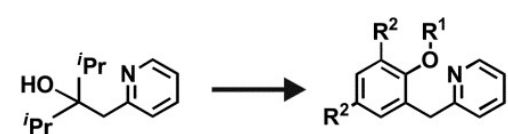

5
$6 \mathrm{R}^{1}=\mathrm{CH}_{3}, \mathrm{R}^{2}=\mathrm{H}$

$7 \mathrm{R}^{1}=\mathrm{H}, \mathrm{R}^{2}=\mathrm{H}$

$8 \mathrm{R}^{1}=\mathrm{CH}_{3}, \mathrm{R}^{2}={ }^{t} \mathrm{Bu}$

$9 \mathrm{R}^{1}=\mathrm{H}, \mathrm{R}^{2}={ }^{t} \mathrm{Bu}$
Scheme 2. Synthesis of the two pyridylphenols from Scheme 1.

\section{Synthesis}

The synthesis of ${ }^{t} \mathrm{Bu}_{2} \mathrm{PhOH}-\mathrm{CH}_{2}$-py had been previously described, ${ }^{[5 c, 5 d, 5]]}$ but in our hands a different procedure turned out to be more convenient for obtaining the two pyridylphenols from Scheme $1 .^{[8]}$ Our synthetic strategy is illustrated by Scheme 2 and begins with commercially available 2-bromophenols ( 1 and 3 ), which are methylated in order to protect the phenolic function for the subsequent reaction step. The protected phenols (2 and 4 ) are reacted with pyridine molecule $\mathbf{5}$ (which is accessible in one step from 2-picoline and diisopropyl ketone) using a palladium catalyst. ${ }^{[8]}$ The coupling products (6 and 8 ) are deprotected using aqueous $\mathrm{HBr}$ (in the case of 6 ) ${ }^{[9]}$ or ethanethiol (in the case of $8)^{[10]}$ in order to obtain the final pyridylphenols $\left(7, \mathrm{PhOH}-\mathrm{CH}_{2}\right.$-py and $9,{ }^{t} \mathrm{Bu}_{2} \mathrm{PhOH}-\mathrm{CH}_{2}-\mathrm{py}$ ).
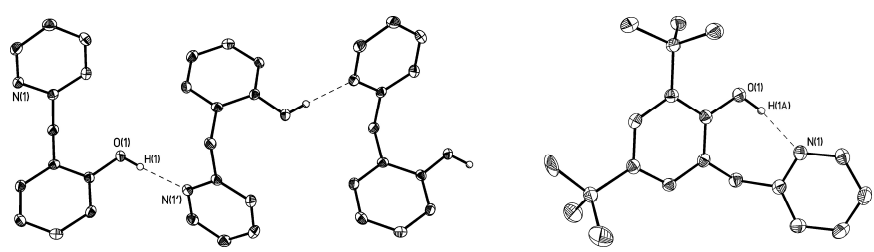

Figure 1. Crystal structures of $\mathrm{PhOH}-\mathrm{CH}_{2}$-py (left) and ${ }^{t} \mathrm{Bu}_{2} \mathrm{PhOH}-\mathrm{CH}_{2}-\mathrm{py}$ (right) Anisotropic displacement parameters are depicted at the $50 \%$ probability level. Selected bond distances and angles can be found in the supporting information.

\section{Crystal structures}

Figure 1 (left) shows the crystal structure of $\mathrm{PhOH}-\mathrm{CH}_{2}$-py which crystallizes in the monoclinic space group $\mathrm{C} 2 / \mathrm{c}$ with one molecule in the asymmetric unit. The molecules in the crystal lattice of $\mathrm{PhOH}-\mathrm{CH}_{2}$-py are connected through intermolecular hydrogen bonds between the phenolic $\mathrm{OH}$ group and the nitrogen of the pyridyl ring. These bonds generate a zigzag like chain along the $b$ axis of the crystal lattice. The position of the hydrogen atom was modeled as a riding atom with a fixed distance of $0.84 \AA$ and a freely refined torsion angle. The resulting hydrogen bond is slightly bent with $175^{\circ}$ for the $\mathrm{O}-\mathrm{H}-\mathrm{N}$ angle and has a $\mathrm{H}-\mathrm{N}$ distance of $1.90 \AA$, resulting in a total $\mathrm{O}-\mathrm{H}-\mathrm{N}$ distance of $2.740(2) \AA$. Figure 1 (right) shows the crystal structure of
${ }^{t} \mathrm{Bu}_{2} \mathrm{PhOH}-\mathrm{CH}_{2}$-py which crystallizes in the monoclinic space group $P 2_{1} / n$ with one molecule in the asymmetric unit. One of the ${ }^{t} \mathrm{Bu}$ groups happens to be disordered by $5 \%$. This molecule only forms an intramolecular hydrogen bond between $\mathrm{H} 1$ and N1. The hydrogen $\mathrm{H} 1$ was found in the difference Fourier density. Position and the isotropic vibration were refined freely with a distance restraint of $0.84(2) \AA$ to 01 . The $\mathrm{O}-\mathrm{H}$ distance refined to $0.88(2) \AA$ with a N-H distance of $1.827(16) \AA$ and a total O-N distance of $2.6956(16) \AA$ with an O-H-N angle of $169(2)^{\circ}$. Thus, there is clear evidence for hydrogen-bonding interactions in the crystal structures of $\mathrm{PhOH}-\mathrm{CH}_{2}$-py and ${ }^{t} \mathrm{Bu}_{2} \mathrm{PhOH}-\mathrm{CH}_{2}-\mathrm{py} \cdot{ }^{[11]} \mathrm{A}$ structure of ${ }^{t} \mathrm{Bu}_{2} \mathrm{PhOH}-\mathrm{CH}_{2}$-py had been previously published. ${ }^{25}$

\section{Intramolecular hydrogen-bonding in solution}

${ }^{1} \mathrm{H}$ NMR spectra of the two pyridylphenols in $\mathrm{CDCl}_{3}$ exhibit sharp downfield resonances for the phenolic protons, specifically at $11.67 \mathrm{ppm}$ for $\mathrm{PhOH}-\mathrm{CH}_{2}$-py and at $11.40 \mathrm{ppm}$ for ${ }^{t} \mathrm{Bu}_{2} \mathrm{PhOH}-$ $\mathrm{CH}_{2}$-py, which is typical for intramolecularly hydrogen-bonded phenols. ${ }^{[12]}$ We conclude that intramolecular hydrogen-bonds are not only present in one of our solid state structures but also in aprotic solution

\section{Cyclic voltammetry}

Figure 2 shows cyclic voltammograms of (a) ${ }^{t} \mathrm{Bu}_{2} \mathrm{PhOH}$, (b) ${ }^{t} \mathrm{Bu}_{2} \mathrm{PhOH}-\mathrm{CH}_{2}$-py, and (c) $\mathrm{PhOH}-\mathrm{CH}_{2}$-py in dry $\mathrm{CH}_{2} \mathrm{Cl}_{2}$ in presence of $0.1 \mathrm{M} \mathrm{TBAPF}_{6}$ electrolyte. The reversible waves at $0.0 \mathrm{~V} \mathrm{vs}$. $\mathrm{Fc}^{+} / \mathrm{Fc}$ (dashed vertical line) are due to ferrocene, which was added in small quantities for internal voltage calibration. The voltammogram of the reference phenol (a) exhibits an irreversible oxidation wave peaking at $1.05 \mathrm{~V}$ vs. $\mathrm{Fc}^{+} / \mathrm{Fc}$ which is typical for ordinary phenols because the $\mathrm{O}-\mathrm{H}$ proton is lost to the bulk solution in the course of oxidation. ${ }^{[13]}$

The ${ }^{t} \mathrm{Bu}_{2} \mathrm{PhOH}-\mathrm{CH}_{2}$-py molecule, by contrast, exhibits a voltammogram in which the oxidative peak current near $0.5 \mathrm{~V}$ vs. $\mathrm{Fc}^{+} / \mathrm{Fc}$ is roughly 6 times larger than the corresponding reductive peak current. Their voltage separation is $170 \mathrm{mV}$ but depends on voltage sweep rate. The voltammogram in Figure $2 b$ is qualitatively similar to that previously reported for the same compound in $\mathrm{CH}_{3} \mathrm{CN}$ solution. ${ }^{[5 c]}$ The shape of this voltammogram can be explained by the possibility of transferring the phenolic proton to the pendant pyridine base in the course of oxidation and back-transfer to the phenol unit during the subsequent reductive potential sweep. The middle between the oxidative and reductive peak currents in Figure $2 \mathrm{~b}$ is taken as the oxidation potential of ${ }^{t} \mathrm{Bu}_{2} \mathrm{PhOH}-\mathrm{CH}_{2}$-py (Table 1). Importantly, the oxidation potential of ${ }^{t} \mathrm{Bu}_{2} \mathrm{PhOH}-\mathrm{CH}_{2}$-py in $\mathrm{CH}_{2} \mathrm{Cl}_{2}$ is about $0.5 \mathrm{~V}$ less positive than the oxidation potential of ${ }^{t} \mathrm{Bu}_{2} \mathrm{PhOH}$, a fact that has been previously noted for $\mathrm{CH}_{3} \mathrm{CN}$ solution. ${ }^{[5 c, 5 \mathrm{~d}]}$ It has been demonstrated that the unusually low oxidation potential of ${ }^{t} \mathrm{Bu}_{2} \mathrm{PhOH}-\mathrm{CH}_{2}$-py and related hydrogen-bonded phenols is a direct manifestation of intramolecular proton transfer accompanying electrochemical phenol oxidation; hydrogenbonding alone cannot account for the large magnitude of the oxidation potential shift. ${ }^{[5 c, 14]}$

The cyclic voltammogram of $\mathrm{PhOH}-\mathrm{CH}_{2}$-py in Figure 2c exhibits an irreversible oxidation wave peaking at $0.66 \mathrm{~V}$ vs. $\mathrm{Fc}^{+} / \mathrm{Fc}$ (Table 1). Despite the presence of an intramolecular hydrogen bond phenol oxidation is clearly irreversible in this case, possibly because of the absence of substituents at the 4- and 6positions of the phenol. Chemical substituents in ortho- and para- 
position to the phenolic function are known to enhance the stability of phenoxyl radicals. ${ }^{[18]}$ By analogy to the other pyridylphenol from Scheme $1 \mathrm{PhOH}-\mathrm{CH}_{2}$-py is oxidized at much less positive potential than the $\mathrm{PhOH}$ reference molecule; in this specific case the potential difference amounts to $\sim 0.6 \mathrm{~V}$ (Table 1).

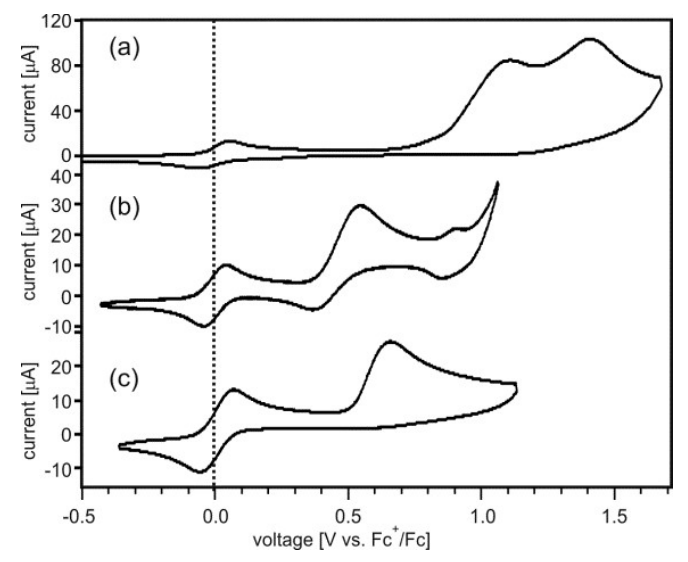

Figure 2. Cyclic voltammograms of the hydrogen-bonded phenols from Scheme 1 in dry $\mathrm{CH}_{2} \mathrm{Cl}_{2}$ in presence of $0.1 \mathrm{M} \mathrm{TBAPF}_{6}$. (a) ${ }^{t} \mathrm{Bu}_{2} \mathrm{PhOH}$; (b) ${ }^{t} \mathrm{Bu}_{2} \mathrm{PhOH}-\mathrm{CH}_{2}$ py; (c) $\mathrm{PhOH}-\mathrm{CH}_{2}-$ py. The reversible waves at $0.0 \mathrm{~V}$ vs. $\mathrm{Fc}^{+} / \mathrm{Fc}$ are due to ferrocene which was added in small quantities for internal voltage calibration; the scan rate was $100 \mathrm{mV} / \mathrm{s}$

Table 1. Electrochemical potentials $(E)$ for oxidation of the four phenol molecules and for reduction of the photoexcited $\left[\operatorname{Re}(\text { phen })(\mathrm{CO})_{3}(\mathrm{py})\right]^{+}$complex.

redox couple $\quad E\left[\mathrm{~V}\right.$ vs. $\left.\mathrm{Fc}^{+} / \mathrm{Fc}\right]$

$\mathrm{PhOH}^{+} / \mathrm{PhOH}$

$1.25^{\text {[a] [d] }}$

$\mathrm{PhOH}-\mathrm{CH}_{2}-\mathrm{py}^{+} / \mathrm{PhOH}-\mathrm{CH}_{2}-\mathrm{py}$

$0.66^{[b]}$

${ }^{t} \mathrm{Bu}_{2} \mathrm{PhOH}^{+} / \mathrm{Bu}_{2} \mathrm{PhOH}$

$0.97^{[b]}$

${ }^{t} \mathrm{Bu}_{2} \mathrm{PhOH}-\mathrm{CH}_{2}-\mathrm{py}^{+} / \mathrm{Bu}_{2} \mathrm{PhOH}-\mathrm{CH}_{2}-\mathrm{py}$

$0.54^{[b]}$

${ }^{*}\left[\operatorname{Re}(\text { phen })(\mathrm{CO})_{3}(\mathrm{py})\right]^{+} /\left[\operatorname{Re}(\right.$ phen $\left.)(\mathrm{CO})_{3}(\mathrm{py})\right]$

$0.77^{[c][d]}$

[a] From reference [15], converted from $\mathrm{V}$ vs. SCE to $\mathrm{V}$ vs. $\mathrm{Fc}^{+} / \mathrm{Fc}$ by subtracting $0.38 \mathrm{~V}$ as described in ref. [16]; [b] Measured in this work, peak potentials from Figure 2, $0.1 \mathrm{M}$ TBAPF 6 electrolyte in $\mathrm{CH}_{2} \mathrm{Cl}_{2}$; [c] from reference [6]; [d] in $\mathrm{CH}_{3} \mathrm{CN}$. The previously reported value for ${ }^{t} \mathrm{Bu}_{2} \mathrm{PhOH}-\mathrm{CH}_{2}-$ py is $0.44 \mathrm{~V}$ vs. $\mathrm{Fc}^{+} / \mathrm{Fc}$ in $\mathrm{CH}_{3} \mathrm{CN}^{[5]}$ The potential of ${ }^{t} \mathrm{Bu}_{2} \mathrm{PhOH}$ is in line with the value reported in ref. ${ }^{[17]}(0.519 \mathrm{~V}$ vs. $\mathrm{NHE}$, addition of $0.624 \mathrm{~V}$ (according to ref. ${ }^{[16]}$ ) gives $1.14 \mathrm{~V}$ vs. $\mathrm{Fc}^{+} / \mathrm{Fc}$ ).

The electrochemistry of the $\left[\operatorname{Re}(\text { phen })(\mathrm{CO})_{3}(\mathrm{py})\right]^{+}$complex and related rhenium(I) tricarbonyl diimines was explored extensively in the past. ${ }^{[7,19]}$ In Table 1 we merely give the electrochemical potential for one-electron reduction of ${ }^{3}$ MLCT-excited $\left[\operatorname{Re}(\text { phen })(\mathrm{CO})_{3}(\mathrm{py})\right]^{+}$as reported in the literature. ${ }^{[6]]}$

\section{Optical absorption}

Figure 3 shows UV-vis spectra of the four phenols and the rhenium(I) complex from Scheme 1 in $\mathrm{CH}_{2} \mathrm{Cl}_{2}$ at $25^{\circ} \mathrm{C}$. The important message from Figure 3 is that all four phenols are spectroscopically innocent at wavelengths longer than $330 \mathrm{~nm}$. Between 270 and $280 \mathrm{~nm}$ they exhibit weak absorptions as previously reported for other phenols; in presence of covalently attached pyridine units the extinction between $270 \mathrm{~nm}$ and 280 $\mathrm{nm}$ increases because pyridine has itself weakly absorbing $n-\pi^{*}$ transitions occurring in this spectral range. ${ }^{[20]}$ As reported previously, the $\left[\operatorname{Re}(\text { phen })(\mathrm{CO})_{3}(\mathrm{py})\right]^{+}$complex exhibits a metal-to- ligand charge transfer (MLCT) band with maxima at $380 \mathrm{~nm}$ and $336 \mathrm{~nm}$, while the absorption maximum at $276 \mathrm{~nm}$ has been attributed to phenanthroline-based electronic transitions. ${ }^{[19 a, 19 b]}$ The most important observation from Figure 3 is that with light of $410 \mathrm{~nm}$ wavelength we can selectively excite the $\left[\operatorname{Re}(\text { phen })(\mathrm{CO})_{3}(\mathrm{py})\right]^{+}$complex even in presence of large excess of any of the four phenols. Furthermore, there is no phenol absorption in the spectral range in which the rhenium(I) complex emits $(450 \mathrm{~nm}-700 \mathrm{~nm})$; this is why in Figure 3 we show the entire spectral range between $250 \mathrm{~nm}$ and $700 \mathrm{~nm}$. We note that phenol has a triplet energy $\left(E_{T}\right)$ of $3.55 \mathrm{eV}^{,[21]}$ while the $\left[\operatorname{Re}(\text { phen })(\mathrm{CO})_{3}(\mathrm{py})\right]^{+}$complex has $\mathrm{E}_{\mathrm{T}} \approx 2.75 \mathrm{eV}^{[7,19 a]}$ hence we can a priori rule out the possibility of ${ }^{3} \mathrm{MLCT}$ excited-state quenching by triplet-triplet energy transfer from $\left[\operatorname{Re}(\text { phen })(\mathrm{CO})_{3}(\mathrm{py})\right]^{+}$to the phenols. ${ }^{[22]}$

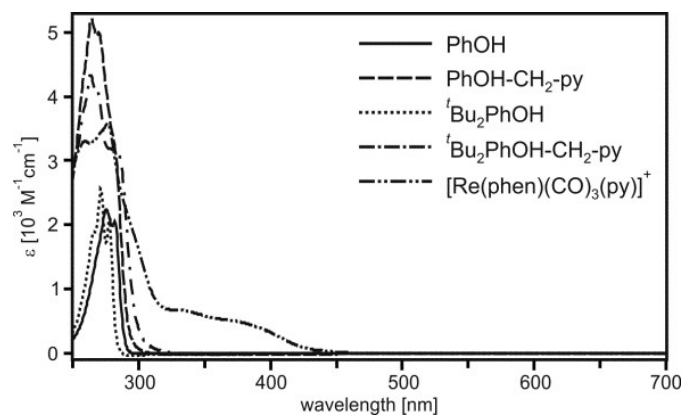

Figure 3. Optical absorption spectra of the four phenols and the rhenium(I) complex from Scheme 1.

\section{Luminescence quenching experiments}

The solid trace in Figure $4 a$ is the emission spectrum of $[\operatorname{Re} \text { (phen)(CO) })_{3}(\text { py) }]^{+}$in aerated $\mathrm{CH}_{2} \mathrm{Cl}_{2}$ with $100 \mathrm{mM} \mathrm{CH} \mathrm{CH}_{3} \mathrm{OH}$ at $25{ }^{\circ} \mathrm{C}$. The excitation wavelength was set at $410 \mathrm{~nm}$. The broad and unstructured luminescence band is due to the typical ${ }^{3} \mathrm{MLCT}$ emission of rhenium(I) tricarbonyl diimines. ${ }^{[19 a]}$ The solid trace in Figure $4 \mathrm{~b}$ shows the temporal evolution of the ${ }^{3} \mathrm{MLCT}$ luminescence from Figure $4 a$ after excitation with $\sim 10$ ns laser pulses at $410 \mathrm{~nm}$; detection occurred at $530 \mathrm{~nm}$. The luminescence intensity decays in a single-exponential manner over more than two orders of magnitude and one extracts a ${ }^{3} \mathrm{MLCT}$ lifetime of $1.2 \mu \mathrm{s}$, in line with previous reports. ${ }^{[19 \mathrm{a}, 19 \mathrm{~b}]}$ The dashed lines in Figure $4 \mathrm{a} / 4 \mathrm{~b}$ were recorded in presence of variable concentrations ( $1 \mathrm{mM}-10 \mathrm{mM}$ ) of $\mathrm{PhOH}$. No significant luminescence quenching is observed with $\mathrm{PhOH}$, neither in intensity (Figure 4a) nor in decay time (Figure 4b). Likewise, when using deuterated phenol (PhOD), the emission intensity stays virtually unchanged (Figure 4c) and the luminescence decays are no faster than in the absence of PhOD (Figure 4d). We conclude that the ordinary phenol is unable to quench the ${ }^{3} \mathrm{MLCT}$ excited state of $\left[\operatorname{Re}(\text { phen })(\mathrm{CO})_{3}(\mathrm{py})\right]^{+}$under the experimental conditions chosen here. 

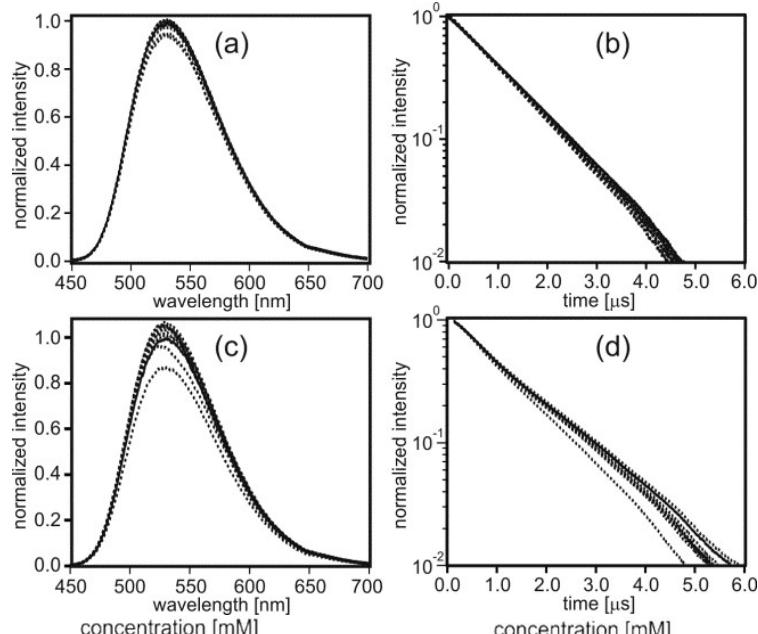

Figure 4. (a) Luminescence of $\left[\operatorname{Re}(\text { phen })(\mathrm{CO})_{3}(\mathrm{py})\right]^{+}$in aerated $\mathrm{CH}_{2} \mathrm{Cl}_{2}$ with 100 $\mathrm{mM} \mathrm{CH} \mathrm{H}_{3} \mathrm{OH}$ in absence (solid line) and presence of increasing amounts of $\mathrm{PhOH}$ (dotted lines; $1 \mathrm{mM}-10 \mathrm{mM}$ ) after excitation at $410 \mathrm{~nm}$; (b) luminescence decays of $\left[\operatorname{Re}(\mathrm{phen})(\mathrm{CO})_{3}(\mathrm{py})\right]^{+}$in the same solvent in absence (solid line) and presence of increasing amounts of $\mathrm{PhOH}$ (dotted lines) after excitation at $410 \mathrm{~nm}$ with laser pulses of $\sim 10 \mathrm{~ns}$ width (detection wavelength: $530 \mathrm{~nm}$ ); (c) same experiment as in (a) but with deuterated phenol (PhOD); (d) same experiment as in (b) but with deuterated phenol (PhOD). All y-axes are in arbitrary units; the intensity of the unquenched emission in (a) and (c) is normalized arbitrarily to 1 ; the intensity at $\mathrm{t}=0$ in (b) and (d) is normalized arbitrarily to 1 .

Figure 5 shows the results of an analogous series of experiments performed with $\mathrm{PhOH}-\mathrm{CH}_{2}$-py. From Figure 5a we learn that the emission intensity of $\left[\operatorname{Re}(\text { phen })(\mathrm{CO})_{3}(\mathrm{py})\right]^{+}$is significantly quenched in the presence of $1 \mathrm{mM}$ to $10 \mathrm{mM} \mathrm{PhOH}-$ $\mathrm{CH}_{2}$-py (dotted traces compared to solid trace). Similarly, the luminescence decays are strongly dependent on the $\mathrm{PhOH}-\mathrm{CH}_{2-}$ py concentration (Figure $5 \mathrm{~b}$ ). When using deuterated $\mathrm{PhOD}-\mathrm{CH}_{2-}$ py the luminescence decays (Figure $5 \mathrm{~d}$ ) are noticeably slower than for undeuterated $\mathrm{PhOH}-\mathrm{CH}_{2}$-py at equal concentration (Figure $5 \mathrm{~b}$ ). Likewise, in the luminescence intensity data of Figure $5 \mathrm{c}$ quenching at a given phenol concentration is noticeably weaker than for the undeuterated quencher in Figure 5a. Thus, there appears to be a significant $H / D$ kinetic isotope effect $(K I E)$.
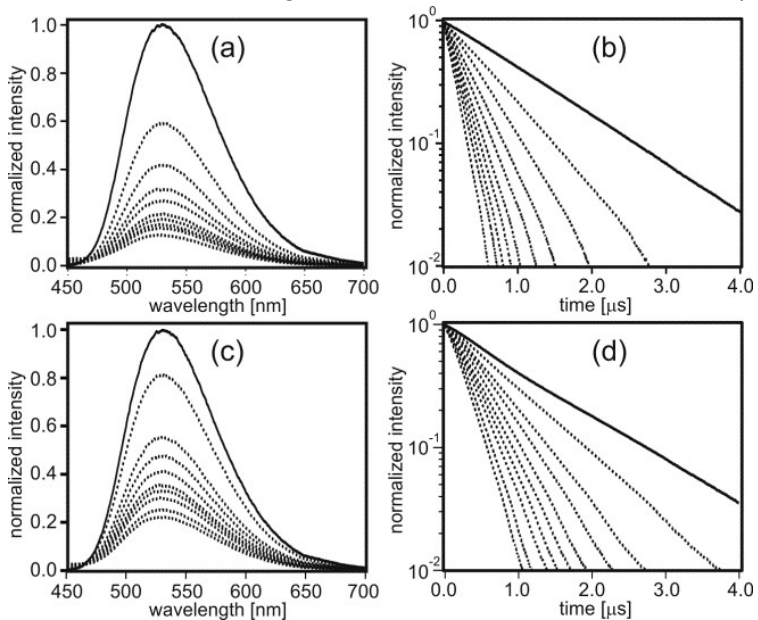

Figure 5. (a) Luminescence of $\left[\mathrm{Re}(\text { phen })(\mathrm{CO})_{3}(\mathrm{py})\right]^{+}$in aerated $\mathrm{CH}_{2} \mathrm{Cl}_{2}$ with 100 $\mathrm{mM} \mathrm{CH} \mathrm{CH}_{3} \mathrm{OH}$ in absence (solid line) and presence of increasing amounts of $\mathrm{PhOH}-\mathrm{CH}_{2}$-py (dotted lines; $1 \mathrm{mM}-10 \mathrm{mM}$ ) after excitation at $410 \mathrm{~nm}$; (b) luminescence decays of $\left[\operatorname{Re}(\text { phen })(\mathrm{CO})_{3}(\mathrm{py})\right]^{+}$in the same solvent in absence (solid line) and presence of increasing amounts of $\mathrm{PhOH}-\mathrm{CH}_{2}$-py (dotted lines) after excitation at $410 \mathrm{~nm}$ with laser pulses of $10 \mathrm{~ns}$ width (detection wavelength: $530 \mathrm{~nm}$ ); (c) same experiment as in (a) but with deuterated phenol
(PhOD-CH $\mathrm{CH}_{2}$-py) and $100 \mathrm{mM} \mathrm{CH}$ OD; (d) same experiment as in (b) but with deuterated phenol (PhOD- $\mathrm{CH}_{2}$-py) and $100 \mathrm{mM} \mathrm{CH} \mathrm{CH}_{3} \mathrm{OD}$. All y-axes are in arbitrary units; the intensity of the unquenched emission in (a) and (c) is normalized arbitrarily to 1 ; the intensity at $t=0$ in (b) and (d) is normalized arbitrarily to 1 .

Figure $6 \mathrm{a}$ is a Stern-Volmer plot based on the luminescence intensity data from Figures $4 / 5$, and Figure $6 b$ is a Stern-Volmer plot based on the luminescence lifetime data from Figures 4/5. ${ }^{[23]}$ The open circles in Figure 6a/6b represent data obtained using $\mathrm{PhOH}-\mathrm{CH}_{2}$-py, the open squares represent data obtained using the deuterated analogue $\mathrm{PhOD}-\mathrm{CH}_{2}-\mathrm{py}$. Linear regression fits yield the Stern-Volmer constants (Ksv) given in the third (ordinary phenols) and fourth column (deuterated phenols) of Table 2.
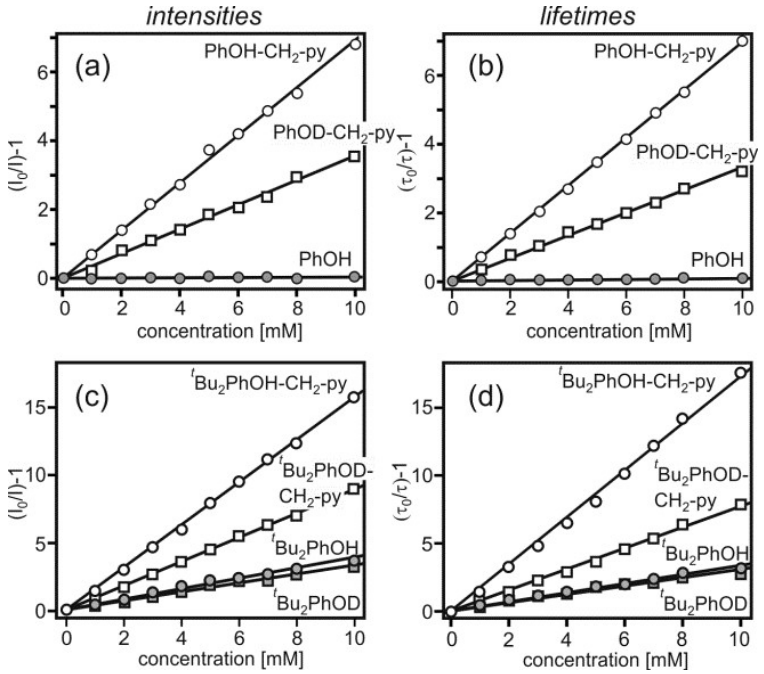

Figure 6. (a) Stern-Volmer plot based on the luminescence intensity data from Figures 4/5; open circles: $\mathrm{PhOH}-\mathrm{CH}_{2}-\mathrm{py}$, open squares: $\mathrm{PhOD}-\mathrm{CH}_{2}-\mathrm{py}$, grey filled circles: $\mathrm{PhOH}$. (b) Stern-Volmer plot based on the luminescence lifetime data from Figures 4/5; open circles: $\mathrm{PhOH}-\mathrm{CH}_{2}-\mathrm{py}$, open squares: $\mathrm{PhOD}-\mathrm{CH}_{2}-$ py, grey filled circles: $\mathrm{PhOH}$. (c) Stern-Volmer plot based on the luminescence intensity data from Figures S1/S2; open circles: ${ }^{t} \mathrm{Bu}_{2} \mathrm{PhOH}-\mathrm{CH}_{2}-\mathrm{py}$, open squares: ${ }^{t} \mathrm{Bu}_{2} \mathrm{PhOD}-\mathrm{CH}_{2}-\mathrm{py}$, grey filled circles: ${ }^{t} \mathrm{Bu}_{2} \mathrm{PhOH}$, grey filled squares: ${ }^{t} \mathrm{Bu}_{2} \mathrm{PhOD}$. (d) Stern-Volmer plot based on the luminescence lifetime data from Figures $\mathrm{S} 1 / \mathrm{S} 2$; open circles: ${ }^{t} \mathrm{Bu}_{2} \mathrm{PhOH}-\mathrm{CH}_{2}$-py, open squares: ${ }^{t} \mathrm{Bu}_{2} \mathrm{PhOD}-\mathrm{CH}_{2}-$ py, grey filled circles: ${ }^{t} \mathrm{Bu} \mathrm{u}_{2} \mathrm{PhOH}$, grey filled squares: ${ }^{t} \mathrm{Bu} \mathrm{u}_{2} \mathrm{PhOD}$.

The H/D KIE mentioned above shows up directly in the SternVolmer constants: From the intensity data in Figure 6 one extracts $\mathrm{K}_{\mathrm{SV}, \mathrm{H}}=691 \pm 7 \mathrm{M}^{-1}$ (for $\mathrm{PhOH}-\mathrm{CH}_{2}$-py) and $\mathrm{K}_{\mathrm{SV}, \mathrm{D}}=355 \pm 5$ $\mathrm{M}^{-1}$ (for PhOD-CH$-\mathrm{Cy}$ ), the lifetime data in Figure $6 \mathrm{~b}$ yield $\mathrm{K}_{\mathrm{SV}, \mathrm{H}}=$ $701 \pm 3 \mathrm{M}^{-1}$ (for $\mathrm{PhOH}-\mathrm{CH}_{2}$-py) and $\mathrm{K}_{\mathrm{sv}, \mathrm{D}}=334 \pm 6 \mathrm{M}^{-1}$ (for PhOD$\mathrm{CH}_{2}$-py). Based on the ${ }^{3} \mathrm{MLCT}$ lifetime of $\left[\operatorname{Re}(\text { phen })(\mathrm{CO})_{3}(\mathrm{py})\right]^{+}$ (1.2 $\mu$ s in aerated $\mathrm{CH}_{2} \mathrm{Cl}_{2}$, see above) we calculate rate constants for bimolecular excited-state quenching of $\mathrm{k}_{\mathrm{Q}, \mathrm{H}}=(5.9 \pm 0.1) \cdot 10^{8} \mathrm{M}^{-1}$ $\mathrm{s}^{-1}$ for $\mathrm{PhOH}-\mathrm{CH}_{2}$-py and $\mathrm{k}_{\mathrm{Q}, \mathrm{D}}=(2.8 \pm 0.1) \cdot 10^{8} \mathrm{M}^{-1} \mathrm{~s}^{-1}$ for PhOD$\mathrm{CH}_{2}$-py (fifth and sixth column of Table 2). ${ }^{[23]}$ The H/D KIE is the ratio between $\mathrm{k}_{\mathrm{Q}, \mathrm{H}}$ and $\mathrm{k}_{\mathrm{Q}, \mathrm{D}}$ and amounts to $2.1 \pm 0.1$ (last column of Table 2). ${ }^{[69]}$ From the luminescence intensity data in Figure $6 a$ one extracts $\mathrm{k}_{\mathrm{Q}, \mathrm{H}}=(5.9 \pm 0.1) \cdot 10^{8} \mathrm{M}^{-1} \mathrm{~s}^{-1}$ for $\mathrm{PhOH}-\mathrm{CH}_{2}$-py and $\mathrm{k}_{\mathrm{Q}}$, $\mathrm{D}=(3.0 \pm 0.1) \cdot 10^{8} \mathrm{M}^{-1} \mathrm{~s}^{-1}$ for PhOD-CH- py, yielding a value of $\mathrm{KIE}$ $(2.0 \pm 0.1)$ in accordance with the lifetime data. 


\begin{tabular}{|c|c|c|c|c|c|c|}
\hline phenol & Exp. type & $\mathrm{Ksv}, \mathrm{H}\left[\mathrm{M}^{-1}\right]$ & $\mathrm{K}_{\mathrm{sv}, \mathrm{D}}\left[\mathrm{M}^{-1}\right]$ & $\mathrm{k}_{Q, H}\left[\mathrm{M}^{-1} \cdot \mathrm{s}^{-1}\right]$ & $\mathrm{K}_{\mathrm{Q}, \mathrm{D}}\left[\mathrm{M}^{-1} \cdot \mathrm{s}^{-1}\right]$ & $\mathrm{KIE}$ \\
\hline \multirow[t]{2}{*}{$\mathrm{PhOH} / \mathrm{D}$} & intensity & $3.4 \pm 1.2$ & $0.5 \pm 3.7$ & $(2.9 \pm 1.0) \cdot 10^{6}$ & $(0.4 \pm 3.1) \cdot 10^{6}$ & $N / A$ \\
\hline & lifetime & $8.4 \pm 0.4$ & $13.8 \pm 1.0$ & $(7.1 \pm 0.3) \cdot 10^{6}$ & $(11.7 \pm 0.8) \cdot 10^{6}$ & $\mathrm{~N} / \mathrm{A}$ \\
\hline \multirow[t]{2}{*}{$\mathrm{PhOH} / \mathrm{D}-\mathrm{CH}_{2}-\mathrm{py}$} & intensity & $691 \pm 7$ & $355 \pm 5$ & $(5.9 \pm 0.1) \cdot 10^{8}$ & $(3.0 \pm 0.1) \cdot 10^{8}$ & $2.0 \pm 0.1$ \\
\hline & lifetime & $701 \pm 3$ & $334 \pm 6$ & $(5.9 \pm 0.1) \cdot 10^{8}$ & $(2.8 \pm 0.1) \cdot 10^{8}$ & $2.1 \pm 0.1$ \\
\hline \multirow[t]{2}{*}{${ }^{t} \mathrm{Bu}_{2} \mathrm{PhOH} / \mathrm{D}$} & intensity & $391 \pm 8$ & $332 \pm 8$ & $(3.3 \pm 0.1) \cdot 10^{8}$ & $(2.8 \pm 0.1) \cdot 10^{8}$ & $1.2 \pm 0.1$ \\
\hline & lifetime & $437 \pm 11$ & $309 \pm 10$ & $(3.7 \pm 0.1) \cdot 10^{8}$ & $(2.6 \pm 0.1) \cdot 10^{8}$ & $1.4 \pm 0.1$ \\
\hline \multirow[t]{2}{*}{${ }^{\mathrm{B}} \mathrm{Bu}_{2} \mathrm{PhOH} / \mathrm{D}-\mathrm{CH}_{2}-\mathrm{py}$} & intensity & $1572 \pm 9$ & $892 \pm 5$ & $(13.3 \pm 0.1) \cdot 10^{8}$ & $(7.6 \pm 0.1) \cdot 10^{8}$ & $1.8 \pm 0.1$ \\
\hline & lifetime & $1648 \pm 8$ & $773 \pm 8$ & $(14.0 \pm 0.1) \cdot 10^{8}$ & $(6.6 \pm 0.1) \cdot 10^{8}$ & $2.1 \pm 0.1$ \\
\hline
\end{tabular}

Stern-Volmer constants obtained from emission intensity or lifetime experiments with normal ( $\left.\mathrm{K}_{\mathrm{sV}, \mathrm{H}}\right)$ and deuterated phenols (Ksv, D). Rate constants for bimolecular excited-state quenching with normal $(\mathrm{KQ}, \mathrm{H})$ and deuterated phenols $(\mathrm{KQ}, \mathrm{D})$; calculated from Ksv, $\mathrm{H}$ and $\mathrm{K}_{\mathrm{sv}, \mathrm{D}}$ values using the lifetime of ${ }^{3} \mathrm{MLCT}$-excited $\left[\mathrm{Re}(\text { phen })(\mathrm{CO})_{3}(\mathrm{py})\right]^{+}$in aerated $\mathrm{CH}_{2} \mathrm{Cl}_{2}$ with $100 \mathrm{mM} \mathrm{CH} 3 \mathrm{OH}(1177 \mathrm{~ns})$. $\mathrm{H} / \mathrm{D}$ kinetic isotope effect $(\mathrm{KIE})$ calculated from the ratio of $\mathrm{k}_{\mathrm{Q}, \mathrm{H}}$ and $\mathrm{k}_{\mathrm{Q}, \mathrm{D}}$

The grey filled circles in Figures $6 \mathrm{a} / 6 \mathrm{~b}$ represent data obtained for the undeuterated reference phenol $\mathrm{PhOH}$. One extracts $\mathrm{K}_{\mathrm{SV}, \mathrm{H}}=3.4 \pm 1.2 \mathrm{M}^{-1}$ from the intensity data in Figure $6 \mathrm{a}$ and $\mathrm{K}_{\mathrm{SV}, \mathrm{H}}=8.4 \pm 0.4 \mathrm{M}^{-1}$ from the lifetime data in Figure $6 \mathrm{~b}$, which in turn yields $\mathrm{k}_{Q, H}$ values on the order of $10^{6} \mathrm{M}^{-1} \mathrm{~s}^{-1}$. This order of magnitude of $\mathrm{k}_{\mathrm{Q}}, \mathrm{H}$ underscores what in principle is already evident from the raw data in Figure 4: Reductive excited-state quenching by $\mathrm{PhOH}$ is not kinetically competitive with other (radiative and nonradiative) deactivation processes of photoexcited $\left[\operatorname{Re}(\text { phen })(C O)_{3}(p y)\right]^{+}$. Thus, even though $k_{Q}, D$ values for deuterated phenol are technically available from the data in Figures $4 c / 4 d$, calculation of an H/D KIE is not meaningful in the case of the simple reference phenol.

Figures $6 c / 6 d$ show Stern-Volmer plots based on $\left[\operatorname{Re}(\text { phen })(\mathrm{CO})_{3}(\mathrm{py})\right]^{+}$luminescence quenching experiments with ${ }^{t} \mathrm{Bu}_{2} \mathrm{PhOH}$ (grey filled circles), ${ }^{t} \mathrm{Bu}_{2} \mathrm{PhOD}$ (grey filled squares), ${ }^{t} \mathrm{Bu}_{2} \mathrm{PhOH}-\mathrm{CH}_{2}$-py (open circles), and ${ }^{t} \mathrm{Bu}_{2} \mathrm{PhOD}-\mathrm{CH}_{2}$-py (open squares). The respective raw data are shown in Figures $\mathrm{S} 1$ and $\mathrm{S} 2$ of the Supporting Information. The bimolecular rate constants for excited-state quenching with ${ }^{t} \mathrm{Bu}_{2} \mathrm{PhOH}$ and its deuterated congener extracted from this data are all around $3 \cdot 10^{8} \mathrm{M}^{-1} \mathrm{~s}^{-1}$ (Table 2), for ${ }^{t} \mathrm{Bu}_{2} \mathrm{PhOH} / \mathrm{D}-\mathrm{CH}_{2}$-py the $\mathrm{k}_{\mathrm{Q}}$-values are about a factor of 3 larger. $\mathrm{H} / \mathrm{D}$ KIEs range from close to 1.0 for ${ }^{\mathrm{t}} \mathrm{Bu}_{2} \mathrm{PhOH}$ to $\sim 2.0$ for ${ }^{\mathrm{t}} \mathrm{Bu}_{2} \mathrm{PhOH}-\mathrm{CH}_{2}-\mathrm{py}$.

All luminescence quenching experiments were performed in presence of $100 \mathrm{mM} \mathrm{CH} \mathrm{CH}_{3} \mathrm{OH} \mathrm{CD}_{3} \mathrm{OD}$ to ensure deuteration of the phenol molecules for the KIE studies. Use of pure $\mathrm{CH}_{2} \mathrm{Cl}_{2}$ or $\mathrm{CD}_{2} \mathrm{Cl}_{2}$ leads to markedly lower KIEs, presumably due to $\mathrm{D} / \mathrm{H}$ exchange of the deuterated phenols when brought into contact with glassware / cuvettes.

Figure 7 shows a plot of the (average) $k_{Q}$ values versus standard Gibbs free energy of reaction $\left(\Delta \mathrm{G}_{\mathrm{ET}} \mathrm{O}^{*}\right)$ associated with electron transfer from the individual phenols to ${ }^{3} \mathrm{MLCT}$-excited $\left[\operatorname{Re}(\text { phen })(\mathrm{CO})_{3}(\mathrm{py})\right]^{+}$. The free energies were calculated based on the redox potentials from Table 1, using the previously determined electrochemical potential for one-electron reduction of photoexcited $\left[\operatorname{Re}(\text { phen })(\mathrm{CO})_{3}(\mathrm{py})\right]^{+}$of $0.77 \mathrm{~V}$ vs. $\mathrm{Fc}^{+} / \mathrm{Fc}$ (bottom row of Table 1). ${ }^{[6]]}$

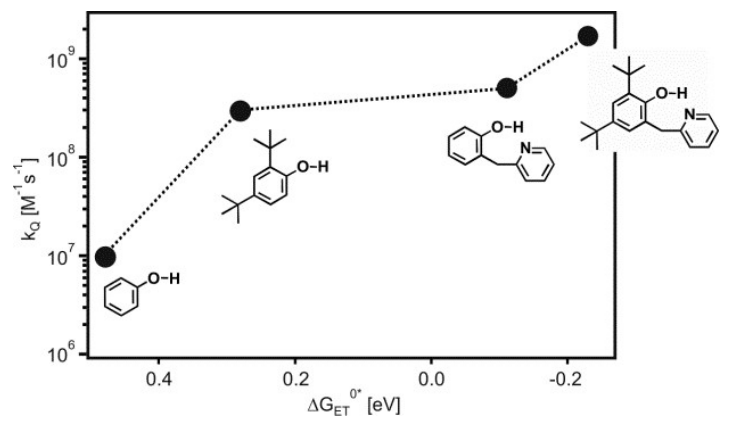

Figure 7. Rate constant ( $\mathrm{K}_{\mathrm{Q}, \mathrm{H}}$; from Table 2) for ${ }^{3} \mathrm{MLCT}$ excited-state quenching of $\left[\operatorname{Re}(\text { phen })(\mathrm{CO})_{3}(\mathrm{py})\right]^{+}$versus driving-force for reductive excited-state quenching $\left(\triangle \mathrm{GET}^{0^{*}}\right.$; estimated on the basis of the data in Table 1).

\section{Transient absorption}

Figure 8a shows the transient absorption spectrum obtained from an acetonitrile solution with $6.7 \cdot 10^{-5} \mathrm{M}\left[\operatorname{Re}(\text { phen })(\mathrm{CO})_{3}(\mathrm{py})\right]^{+}$and $10 \mathrm{mM}{ }^{t} \mathrm{Bu}_{2} \mathrm{PhOH}-\mathrm{CH}_{2}$-py. Selective excitation of the rhenium(I) complex occurred at $355 \mathrm{~nm}$ (Figure 2) with laser pulses of $\sim 10$ $\mathrm{ns}$ width. The data was time-averaged in a window ranging from 0 to $200 \mathrm{~ns}$ after the excitation pulse. The spectrum in Figure $8 \mathrm{a}$ exhibits the signatures of the reduced rhenium tricarbonyl diimine complex and neutral phenoxyl radical at the same time. The intense narrow band centered around $315 \mathrm{~nm}$ and the weaker featureless band extending from $\sim 340 \mathrm{~nm}$ to nearly $550 \mathrm{~nm}$ is typical for the one-electron reduced form of the rhenium complex considered here. ${ }^{[6 e, 24]}$ On the other hand, the narrow peaks at $390 \mathrm{~nm}$ and $409 \mathrm{~nm}$ (dashed vertical arrows) are due to the phenoxyl radical as becomes evident from comparison to the spectrum in Figure 8b. The latter spectrum was recorded after 355-nm excitation of a $\mathrm{CH}_{3} \mathrm{CN}$ solution containing $2 \mathrm{mM}$ ${ }^{t} \mathrm{Bu}_{2} \mathrm{PhOH}-\mathrm{CH}_{2}$-py, $5 \mathrm{mM}$ 1,4-dicyanonaphthalene, and $0.3 \mathrm{M}$ biphenyl. These reaction conditions (making use of 1,4dicyanonaphthalene as a photosensitizer and biphenyl as a codonor) represent an efficient means for the photogeneration of neutral phenoxyl radicals. ${ }^{[25]}$ In presence of phenol the spectral signatures of reduced 1,4-dicyanonaphthalene and oxidized biphenyl have disappeared within $6 \mu \mathrm{s}$, and hence when detecting with a delay of $6.6 \mu$ s after the 10-ns laser pulse one obtains the spectrum shown in Figure $8 \mathrm{~b}$, representing the 
absorption spectrum of the phenoxyl radical of ${ }^{t} \mathrm{Bu}_{2} \mathrm{PhOH}-\mathrm{CH}_{2-}$ py. ${ }^{[25-26]}$ The observation of the same spectral features in Figure $8 \mathrm{a}$ is direct evidence for a PCET reaction, since one detects the oxidized and deprotonated form of the phenol in addition to the reduced form of the rhenium(I) reaction partner. The proton acceptor site is most likely the pyridine unit of ${ }^{t} \mathrm{Bu}_{2} \mathrm{PhOH}-\mathrm{CH}_{2}$-py but this cannot be monitored by transient absorption spectroscopy.

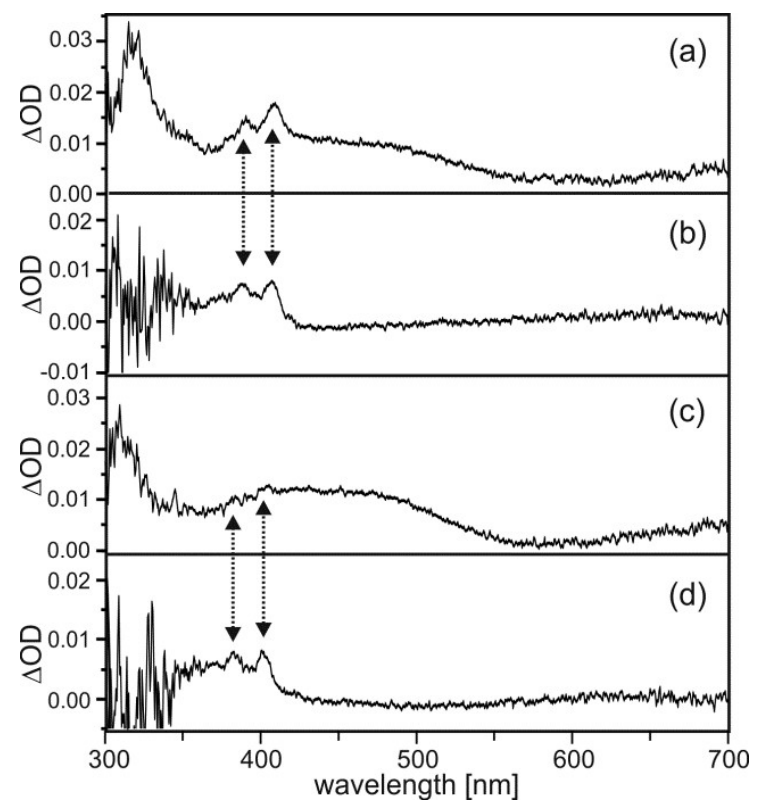

Figure 8. Transient absorption spectra measured in a time window ranging from 0 to $200 \mathrm{~ns}$ after excitation with 10-ns laser pulses at $355 \mathrm{~nm}$. (a) $6.7 \cdot 10^{-5} \mathrm{M}$ $\mathrm{CH}_{3} \mathrm{CN}$ solution of $\left.[\mathrm{Re} \text { (phen)(CO) })_{3}(\mathrm{py})\right]^{+}$with $10 \mathrm{mM}{ }^{t} \mathrm{Bu}_{2} \mathrm{PhOH}-\mathrm{CH}_{2}-$ py; (b) 2 $\mathrm{mM} \mathrm{CH} \mathrm{CHN}_{3}$ solution of ${ }^{t} \mathrm{Bu}_{2} \mathrm{PhOH}-\mathrm{CH}_{2}$-py with $5 \mathrm{mM}$ 1,4-dicyanonaphthalene and $0.3 \mathrm{M}$ biphenyl; this set of data was detected with a time delay of $6.6 \mu \mathrm{s}$ after the excitation pulses. (c) $6.7 \cdot 10^{-5} \mathrm{M} \mathrm{CH}_{3} \mathrm{CN}$ solution of $\left[\operatorname{Re}(\text { phen })(\mathrm{CO})_{3}(\mathrm{py})\right]^{+}$with $19.6 \mathrm{mM} \mathrm{PhOH}-\mathrm{CH}_{2}-$ py; (d) $2.1 \mathrm{mM} \mathrm{CH} \mathrm{CN}_{3}$ solution of $\mathrm{PhOH}-\mathrm{CH}_{2}$-py with $5 \mathrm{mM} \mathrm{1,4-dicyanonaphthalene} \mathrm{and} 0.3 \mathrm{M}$ biphenyl; this set of data was detected with a time delay of $6.6 \mu$ s after the excitation pulses.

Figure $8 \mathrm{c}$ and $8 \mathrm{~d}$ show data from experiments which are analogous to those in Figures $8 \mathrm{a}$ and $8 \mathrm{~b}$ but using solutions with $\mathrm{PhOH}-\mathrm{CH}_{2}$-py instead of ${ }^{t} \mathrm{Bu}_{2} \mathrm{PhOH}-\mathrm{CH}_{2}$-py. Qualitatively similar transient absorption spectra are obtained, but the phenoxyl radical signals are markedly weaker for $\mathrm{PhOH}-\mathrm{CH}_{2}$-py than for ${ }^{t} \mathrm{Bu}_{2} \mathrm{PhOH}-\mathrm{CH}_{2}$-py. However, careful inspection of the data in Figure $8 \mathrm{c}$ reveals that the respective signals, observed at $382 \mathrm{~nm}$ and $402 \mathrm{~nm}$ in Figure 8d, are indeed detectable in the rhenium / $\mathrm{PhOH}-\mathrm{CH}_{2}$-py mixture (dashed vertical arrows). We note that phenoxyl radicals typically have extinction coefficients on the order of $3000 \mathrm{I} \cdot \mathrm{mol}^{-1} \cdot \mathrm{cm}^{-1},{ }^{[26]}$ hence the weakness of some of the signals in Figure 8 is not particularly unusual. At any rate the data provides direct evidence for PCET photoproducts in both rhenium(I) / pyridylphenol reaction couples.

\section{Conclusion}

The hydrogen-bonded pyridylphenols from Scheme 1 quench the ${ }^{3} \mathrm{MLCT}$ excited-state of $\left[\operatorname{Re}(\text { phen })(\mathrm{CO})_{3}(\mathrm{py})\right]^{+}$at significantly higher rates than ordinary reference phenols. This observation is in line with the substantially lower oxidation potentials $(\sim 0.5 \mathrm{~V})$ of the pyridylphenols relative to the reference phenols. The lower oxidation potentials in turn are the result of proton-coupled oxidation processes, as demonstrated in prior studies. ${ }^{[2 e, 5 d, 5 n]}$
Thus we conclude that in the $\mathrm{PhOH}-\mathrm{CH}_{2}$-py / rhenium(I) and ${ }^{t} \mathrm{Bu}_{2} \mathrm{PhOH}-\mathrm{CH}_{2}$-py / rhenium(I) reaction couples considered here the overall quenching process is a CPET reaction involving electron transfer from the phenols to the photoexcited metal complex and transfer of the phenolic proton to the pyridine base. Transient absorption data support this conclusion because they provide direct evidence for the photogeneration of neutral phenoxyl radicals. H/D kinetic isotope effects on the order of 2 point to the involvement of concerted proton-electron transfer in the excited-state chemistry, in line with the prior notion that the oxidation potentials of the pyridylphenols can only be that much lower than those of ordinary phenols $(\sim 0.5 \mathrm{~V})$ because electron release is inherently coupled to deprotonation. ${ }^{[2 e, 5 d, 5 n]}$

Interestingly, excited-state quenching with ${ }^{t} \mathrm{Bu}_{2} \mathrm{PhOH}$ by simple electron transfer is already quite efficient $\left((3.3 \pm 0.1) \cdot 10^{8} \mathrm{M}^{-1}\right.$ $\left.\mathrm{s}^{-1}\right)$, yet ${ }^{t} \mathrm{Bu}_{2} \mathrm{PhOH}-\mathrm{CH}_{2}$-py quenches the rhenium ${ }^{3} \mathrm{MLCT}$ state even more rapidly $\left((13.3 \pm 0.1) \cdot 10^{8} \mathrm{M}^{-1} \mathrm{~s}^{-1}\right)$ and with an H/D KIE of $\sim 2$, suggesting that CPET stays kinetically highly competitive with an electron transfer / proton transfer sequence even in a situation in which the initial electron transfer step is thermodynamically possible

\section{Experimental Section}

A suspension of $\mathrm{NaH}(60 \%$ in mineral oil, $1.20 \mathrm{~g}, 30 \mathrm{mmol})$ in anhydrous THF $(6 \mathrm{ml})$ was cooled to $0^{\circ} \mathrm{C}$ and a solution of 2bromophenol (1) $(3.44 \mathrm{~g}, 20 \mathrm{mmol})$ in anhydrous THF (8 ml) was added dropwise over 1 hour under $\mathrm{N}_{2}$ atmosphere. After stirring for an additional 10 minutes iodomethane $(9.2 \mathrm{~g}, 64.8 \mathrm{mmol})$ was added, and the mixture was allowed to warm up to room temperature prior to refluxing for 19 hours. After cooling back to room temperature water was added $(160 \mathrm{ml})$, and the product was extracted with pentane $(3 \times$ $100 \mathrm{ml})$. The combined organic phases were dried over anhydrous $\mathrm{MgSO}_{4}$, and the solvent was removed on a rotary evaporator. Subsequent purification on silica gel with $\mathrm{CH}_{2} \mathrm{Cl}_{2}$ as an eluent $\left(\mathrm{R}_{\mathrm{f}} \approx\right.$ $0.3)$ gave 1-bromo-2-methoxybenzene (2) in $97 \%$ yield. ${ }^{[27]}{ }^{1} \mathrm{H}$ NMR $\left(300 \mathrm{MHz}, \mathrm{CDCl}_{3}\right): \delta(\mathrm{ppm})=3.89(\mathrm{~s}, 3 \mathrm{H}), 6.78-6.95(\mathrm{~m}, 2 \mathrm{H}), 7.27$ $(\mathrm{td}, J=8.2,6.1 \mathrm{~Hz}, 1 \mathrm{H}), 7.54(\mathrm{dd}, J=7.8,1.6 \mathrm{~Hz}, 1 \mathrm{H})$.

The same procedure using identical molar quantities of starting materials was employed for the synthesis of 1-bromo-3,5-di-tert-butyl2-methoxybenzene (4) from 2-bromo-4,6-di-tert-butylphenol (3). On silica gel using $\mathrm{CH}_{2} \mathrm{Cl}_{2}$ as an eluent, product 4 has $\mathrm{R}_{\mathrm{f}} \approx 0.6$, the yield was $97 \%$. ${ }^{1} \mathrm{H} \mathrm{NMR}\left(300 \mathrm{MHz}, \mathrm{CDCl}_{3}\right): \delta(\mathrm{ppm})=1.30(\mathrm{~s}, 9 \mathrm{H}), 1.40(\mathrm{~s}$, $9 \mathrm{H}), 3.91$ (s, $3 \mathrm{H}), 7.28$ (d, J = 2.4 Hz, $1 \mathrm{H}), 7.41$ (d, $J=2.4 \mathrm{~Hz}, 1 \mathrm{H}$ ).

For the synthesis of molecule 5 a solution of 2-picoline $(200 \mathrm{mmol})$ in anhydrous THF $(200 \mathrm{ml})$ was cooled to $-30^{\circ} \mathrm{C}$ and $1.6 \mathrm{M} \mathrm{n}$ butyllithium in hexane $(200 \mathrm{mmol})$ was added slowly. After stirring at this temperature for 30 minutes diisopropyl ketone was added slowly, and the reaction mixture was stirred for another 2 hours at room temperature. Subsequently water $(300 \mathrm{ml})$ was added and the resulting mixture was extracted with ethyl acetate $(3 \times 200 \mathrm{ml})$. The combined organic phases were dried over anhydrous $\mathrm{MgSO}_{4}$, and the solvent was removed using a rotary evaporator. The raw product was purified by column chromatography on silica gel using a $3: 1$ (v:v) mixture of pentane and ethyl acetate as an eluent $\left(R_{f} \approx 0.6\right)$. This procedure afforded pure molecule 5 in $83 \%$ yield. ${ }^{[8]}{ }^{1} \mathrm{H}$ NMR $(300$ $\left.\mathrm{MHz}, \mathrm{CDCl}_{3}\right): \delta(\mathrm{ppm})=0.88(\mathrm{dd}, J=6.9,4.9 \mathrm{~Hz}, 12 \mathrm{H}), 1.90(\mathrm{~m}, 2 \mathrm{H})$ $2.98(\mathrm{~s}, 2 \mathrm{H}), 6.29(\mathrm{~s}, 1 \mathrm{H}), 7.08-7.13(\mathrm{~m}, 1 \mathrm{H}), 7.15(\mathrm{~d}, J=7.8 \mathrm{~Hz}, 1$ H), 7.58 (td, $J=7.7,1.9 \mathrm{~Hz}, 1 \mathrm{H}$ ), 8.43 (ddd, $J=4.9,1.8,0.9 \mathrm{~Hz}, 1 \mathrm{H}$ ).

Using a heat gun $\mathrm{Cs}_{2} \mathrm{CO}_{3}(27.90 \mathrm{~g}, 85.6 \mathrm{mmol})$ was dried under vacuum. Subsequently, palladium trifluoroacetate $(1.18 \mathrm{~g}, 3.6 \mathrm{mmol})$, tricyclohexylphosphine $(2.00 \mathrm{~g}, 7.1 \mathrm{mmol})$, dry p-xylene $(150 \mathrm{ml}), 1-$ bromo-2-methoxybenzene $(2)(16.00 \mathrm{~g}, 85.6 \mathrm{mmol})$, and pyridine 5 
(14.70 g, $71.3 \mathrm{mmol}$ ) were added under nitrogen. The reaction mixture was refluxed under $\mathrm{N}_{2}$ overnight. After cooling to room temperature the mixture was filtered, and the solvent was evaporated under reduced pressure. Column chromatography on silica gel using a $5: 1(v: v)$ mixture of pentane and ethyl acetate $\left(R_{f} \approx 0.1\right)$ afforded the coupling product 6 as a yellow liquid in $73 \%$ yield. ${ }^{[8]}{ }^{1} \mathrm{H}$ NMR (300 $\left.\mathrm{MHz}, \mathrm{CDCl}_{3}\right): \delta(\mathrm{ppm})=3.80(\mathrm{~s}, 3 \mathrm{H}), 4.17(\mathrm{~s}, 2 \mathrm{H}), 6.90$ (ddd, J = 8.1, 6.3, $2.6 \mathrm{~Hz}, 2 \mathrm{H}), 7.03-7.14(\mathrm{~m}, 2 \mathrm{H}), 7.14-7.26(\mathrm{~m}, 2 \mathrm{H}), 7.54$ (td, $J=$ 7.7, $1.9 \mathrm{~Hz}, 1 \mathrm{H}), 8.49-8.58(\mathrm{~m}, 1 \mathrm{H})$.

Molecule 6 ( $0.15 \mathrm{~g}, 0.78 \mathrm{mmol})$ was dissolved in aqueous $\mathrm{HBr}(47 \%$ $4 \mathrm{ml}$ ) and the mixture was refluxed for 19 hours. ${ }^{[9]}$ After evaporation of excess acid, water was added to the solid residue, and the solution was neutralized by addition of an aqueous $\mathrm{K}_{2} \mathrm{CO}_{3}$ solution. The product (7) was extracted with $\mathrm{CH}_{2} \mathrm{Cl}_{2}$, and the combined organic phases were dried over anhydrous $\mathrm{MgSO}_{4}$ prior to solvent removal on a rotary evaporator. The raw product was purified by column chromatography on silica gel using $\mathrm{CH}_{2} \mathrm{Cl}_{2}$ as an eluent $\left(\mathrm{R}_{\mathrm{f}} \approx 0.4\right)$ affording product 7 ( $\mathrm{PhOH}-\mathrm{CH}_{2}$-py) as a white solid in $57 \%$ yield. ${ }^{1} \mathrm{H}$ $\operatorname{NMR}\left(300 \mathrm{MHz}, \mathrm{CDCl}_{3}\right): \delta(\mathrm{ppm})=4.10(\mathrm{~s}, 2 \mathrm{H}), 6.82(\mathrm{td}, J=7.4,1.3$ $\mathrm{Hz}, 1 \mathrm{H}), 6.95-7.02(\mathrm{~m}, 1 \mathrm{H}), 7.13-7.21(\mathrm{~m}, 3 \mathrm{H}), 7.32(\mathrm{~d}, J=7.8 \mathrm{~Hz}, 1$ H), 7.69 (td, $J=7.7,1.8 \mathrm{~Hz}, 1 \mathrm{H}), 8.46(\mathrm{ddd}, J=5.0,1.8,0.8 \mathrm{~Hz}, 1 \mathrm{H}$ ), $11.67(\mathrm{~s}, 1 \mathrm{H}) \cdot{ }^{13} \mathrm{C}$ NMR $\left(75 \mathrm{MHz}, \mathrm{CDCl}_{3}\right): \delta(\mathrm{ppm})=41.7,118.5$, $119.9,121.9,122.8,126.2,128.7,130.2,138.2,147.8,156.7,161.0$ MS $(E I)(m / z)=186.0921\left([M+H]^{+}\right.$, calc.: 186.0913). Anal. calcd. for $\mathrm{C}_{13} \mathrm{H}_{13} \mathrm{NO}$ (\%): C: $77.81, \mathrm{H}: 5.99, \mathrm{~N}: 7.56$; found: C: $77.63, \mathrm{H}: 5.97, \mathrm{~N}$ : 7.47

For the synthesis of molecule 8 from 1-bromo-3,5-di-tert-butyl-2methoxybenzene (4) and pyridine 5 the same procedure as described above for molecule 6 was used. ${ }^{[8]}$ The quantities of reactants used in this case were as follows: $\mathrm{Cs}_{2} \mathrm{CO}_{3}: 22.81 \mathrm{~g}, 70.0 \mathrm{mmol}$; palladium trifluoroacetate: $0.97 \mathrm{~g}, 2.9 \mathrm{mmol}$; tricyclohexylphosphine: $1.63 \mathrm{~g}, 5.8$ mmol; dry p-xylene: $150 \mathrm{ml}$; 1-bromo-3,5-di-tert-butyl-2methoxybenzene (4): $20.86 \mathrm{~g}, 70 \mathrm{mmol}$; pyridine 5: $12.10 \mathrm{~g}, 58.3$ $\mathrm{mmol}$. Using the same chromatography conditions as described above for molecule $\mathbf{6}$, the $R_{f}$ value is $\sim 0.3$, and molecule 8 was obtained in $69 \%$ yield as a yellow oil. ${ }^{1} \mathrm{H} \mathrm{NMR}\left(300 \mathrm{MHz}, \mathrm{CDCl}_{3}\right)$ : $\delta$ $(\mathrm{ppm})=1.26(\mathrm{~s}, 9 \mathrm{H}), 1.43(\mathrm{~s}, 9 \mathrm{H}), 3.75(\mathrm{~s}, 3 \mathrm{H}), 4.27(\mathrm{~s}, 2 \mathrm{H}), 6.98$ $7.17(\mathrm{~m}, 3 \mathrm{H}), 7.26-7.31(\mathrm{~m}, 1 \mathrm{H}), 7.56$ (td, $J=7.7,1.9 \mathrm{~Hz}, 1 \mathrm{H}), 8.57$ (ddd, $J=4.9,1.8,0.9 \mathrm{~Hz}, 1 \mathrm{H}$ )

When subjecting molecule 8 to the same methoxyl-deprotection reaction with aqueous $\mathrm{HBr}$ as described above for molecule 6, not only the methoxyl-group but also the tert.-butyl substituents of molecule 8 were cleaved off and the reaction afforded molecule 7 . It was therefore necessary to apply the following procedure in order to obtain molecule $9:^{[10]}$ To a suspension of $\mathrm{NaH}(60 \%$ in mineral oil, $0.31 \mathrm{~g}, 12.8 \mathrm{mmol})$ in dry $N, N$-dimethylformamide under $\mathrm{N}_{2}$ atmosphere ethanethiol $(0.69 \mathrm{~g}, 11.2 \mathrm{mmol})$ was added dropwise. Then molecule $8(0.50 \mathrm{~g}, 1.6 \mathrm{mmol})$ was added and the reaction mixture was stirred at $100{ }^{\circ} \mathrm{C}$ overnight. After cooling to room temperature, $\mathrm{H}_{2} \mathrm{O}(4 \mathrm{ml}), 1 \mathrm{M}$ aqueous $\mathrm{HCl}(13 \mathrm{ml})$ and phosphate buffer $(0.5 \mathrm{M}, \mathrm{pH}=7)$ were added, and the mixture was extracted with diethyl ether $(3 \times 50 \mathrm{ml})$. The combined organic phases were dried over anhydrous $\mathrm{MgSO}_{4}$, and the solvent was removed on a rotary evaporator. Purification by three successive chromatography columns on silica gel using a 7:3 (v:v) pentane/dichloromethane mixture $\left(\mathrm{R}_{\mathrm{f}} \approx\right.$ $0.5)$ gave product 9 ( ${ }^{t} \mathrm{Bu}_{2} \mathrm{PhOH}-\mathrm{CH}_{2}$-py) in $65 \%$ yield as a white solid. ${ }^{1} \mathrm{H}$ NMR $\left(300 \mathrm{MHz}, \mathrm{CDCl}_{3}\right): \delta(\mathrm{ppm})=1.31(\mathrm{~s}, 9 \mathrm{H}), 1.47(\mathrm{~s}, 9 \mathrm{H})$ $4.10(\mathrm{~s}, 2 \mathrm{H}), 7.06(\mathrm{~d}, J=2.5 \mathrm{~Hz}, 1 \mathrm{H}), 7.17$ (ddd, $J=7.6,5.0,1.1 \mathrm{~Hz}$ $1 \mathrm{H}), 7.24$ (d, $J=2.4 \mathrm{~Hz}, 1 \mathrm{H}), 7.34(\mathrm{~d}, J=7.8 \mathrm{~Hz}, 1 \mathrm{H}), 7.67$ (td, $J=$ 7.7, $1.8 \mathrm{~Hz}, 1 \mathrm{H}$ ), 8.45 (ddd, $J=5.0,1.7,0.9 \mathrm{~Hz}, 1 \mathrm{H}), 11.40(\mathrm{~s}, 1 \mathrm{H}$ ). ${ }^{13} \mathrm{C}$ NMR $\left(75 \mathrm{MHz}, \mathrm{CDCl}_{3}\right): \delta(\mathrm{ppm})=28.8,30.7,33.2,34.1,41.2$, $120.7,121.7,122.0,123.9,125.3,136.9,137.0,140.4,146.6,151.8$ 160.5. MS $(\mathrm{El})(\mathrm{m} / \mathrm{z})=298.2168\left([\mathrm{M}+\mathrm{H}]^{+}\right.$, calc.: 298.2165). Anal calcd. for $\mathrm{C}_{20} \mathrm{H}_{27} \mathrm{NO} \cdot 0.1 \mathrm{C}_{2} \mathrm{H}_{6} \mathrm{NO} \cdot 0.5 \mathrm{C}_{5} \mathrm{H}_{12}$ (\%): C: $80.35, \mathrm{H}: 9.97, \mathrm{~N}$ : 4.52; found: C: $80.29, \mathrm{H}: 10.02, \mathrm{~N}: 4.63$

Deuteration of the phenolic functions occurred by dissolving the individual phenol molecules in a 1:1 mixture of $\mathrm{CH}_{3} \mathrm{CN}$ and $\mathrm{D}_{2} \mathrm{O}$
(99.9\%) followed by subsequent solvent removal on a rotary evaporator; this procedure was accomplished twice in order to ensure high isotope purity. Luminescence quenching experiments in $\mathrm{CH}_{2} \mathrm{Cl}_{2}$ occurred in presence of $100 \mathrm{mM} \mathrm{CD}_{3} \mathrm{OD}$ (99.99\%) in order to avoid significant $\mathrm{D} / \mathrm{H}$ exchange through contact of the phenols with glassware and cuvettes. For experiments with undeuterated phenols, $100 \mathrm{mM} \mathrm{CH}_{3} \mathrm{OH}$ was added.

The $\left[\operatorname{Re}(\text { phen })(\mathrm{CO})_{3}(\mathrm{py})\right]^{+}$complex was available from prior studies in the form of its hexafluorophosphate salt. ${ }^{[6 e, 6 f]}$

${ }^{1} \mathrm{H}$ and ${ }^{13} \mathrm{C}$ NMR spectra were measured on a Bruker B-ACS-120 instrument. Electron-impact mass spectrometry was made with a Finnigan MAT 95 spectrometer. Elemental analyses were performed with a Vario EL3 instrument. For cyclic voltammetry a Versastat3-200 potentiostat from Princeton Applied Research was used. A glassy carbon working electrode, a platinum counter electrode, and a silver quasi-reference electrode were employed. $0.1 \mathrm{M}$ tetrabutylammonium hexafluorophosphate $\left(\mathrm{TBAPF}_{6}\right)$ was used as an electrolyte; prior to voltage sweeps at rates of $0.1 \mathrm{~V} / \mathrm{s}$ the solvent was flushed with nitrogen. Optical absorption spectra were recorded on a Cary 5000 instrument from Varian, steady-state luminescence experiments were performed on a Fluorolog-3 apparatus from Horiba Jobin-Yvon. Luminescence lifetime experiments were performed in Geneva using a home-built setup comprised of a Quantel Brilliant Nd:YAG laser with an integrated magic prism OPO as an excitation source and a detection system consisting of a Spex 270M monochromator, an R928 photomultiplier from Hamamatsu, and a Tektronix TDS 540B digital oscilloscope. Transient absorption experiments were performed in Göttingen using an LP920-KS instrument from Edinburgh Instruments equipped with an iCCD camera from Andor and a Quantel Brilliant b laser as an excitation source.

For the X-ray structures crystals of $\mathbf{7}$ and $\mathbf{9}$ were grown by slow evaporation of the solvent at room temperature. They were selected and mounted with inert oil on a kapton MicroMount. The data of 7 were collected at $100 \mathrm{~K}$ on a Bruker Apex II Ultra with mirror optics. The data of $\mathbf{9}$ were collected on a Bruker smart Apex II Quazar with an Incoatec I $\mu S .{ }^{[28]}$ Data reduction was performed with SAINT, ${ }^{[29]}$ and an empirical absorption correction with SADABS ${ }^{[30]}$ was applied. The structures were solved by direct methods (SHELXS-97) ${ }^{[31]}$ and refined by full-matrix least-squares methods against $F^{2}$ with SHELXL-97 ${ }^{[31]}$ and the shelXle ${ }^{[32]}$ GUI. All non-hydrogen atoms were refined with anisotropic displacement parameters. The hydrogen atoms were refined isotropically on calculated positions using a riding model with their $U_{\text {iso }}$ values constrained to 1.5 times the $U_{\text {eq }}$ of their pivot atoms for terminal $\mathrm{sp}^{3}$ carbon atoms and 1.2 times for all other carbon atoms Crystallographic data (excluding structure factors) for the structures reported in this paper have been deposited with the Cambridge Crystallographic Data Centre. The CCDC numbers, crystal data and experimental details for the X-ray measurements are listed in the supporting information. CCDC 887369 (7) and 887370 (9) contain the supplementary crystallographic data for this paper. These data can be obtained free of charge from The Cambridge Crystallographic Data Centre via www.ccdc.cam.ac.uk/data request/cif.

\section{Acknowledgements}

This research was supported by the Swiss National Science Foundation (SNSF) through grant number PP002-110611, by the Danish National Research Foundation (DNRF) funded Center for Materials Crystallography (CMC), and by the Deutsche Forschungsgemeinschaft (DFG) through IRTG-1422 and through grant number INST186/872-1. The MWK Niedersachsen is thanked for co-funding the transient absorption spectrometer. J. M. Mayer and T. F. Markle are acknowledged for valuable discussions. 
Keywords: Electron transfer; proton transfer; photochemistry transient absorption; luminescence

[1] a) I. Bertini, H. B. Gray, E. I. Stiefel, J. S. Valentine, Biological Inorganic Chemistry, University Science Books, Sausalito, California 2007; b) G. Renger, T. Renger, Photosynth. Res. 2008, 98, 53-80. a) B. A. Barry, G. T. Babcock, Proc. Natl. Acad. Sci. U. S. A. 1987, 84, 7099-7103; b) S. Y. Reece, D. G. Nocera, Annu. Rev. Biochem. 2009, 78, 673-699; c) T. J. Meyer, M. H. V. Huynh, H. H. Thorp, Angew. Chem. Int. Ed. 2007, 46, 5284-5304; d) M. H. V. Huynh, T. J. Meyer, Chem. Rev. 2007, 107, 5004-5064; e) J. M. Mayer, I. J. Rhile, F. B. Larsen, E. A. Mader, T. F. Markle, A. G. DiPasquale, Photosynth. Res. 2006, 87, 3-20; f) J. L. Dempsey, J. R. Winkler, H. B. Gray, Chem. Rev. 2010, 110, 7024-7039; g) S. Hammes-Schiffer, A. A. Stuchebrukhov, Chem. Rev. 2010, 110, 6939-6960; h) J. J. Warren, J. R. Winkler, H. B. Gray, FEBS Lett. 2012, 586, 596-602. a) L. Benisvy, R. Bittl, E. Bothe, C. D. Garner, J. McMaster, S. Ross, C. Teutloff, F. Neese, Angew. Chem. Int. Ed. 2005, 44, 5314-5317; b) T. Maki, Y. Araki, Y. Ishida, O. Onomura, Y. Matsumura, J. Am. Chem. Soc. 2001, 123, 3371-3372; c) T. Lachaud, A. Quaranta, Y. Pellegrin, P. Dorlet, M. F. Charlot, S. Un, W. Leibl, A. Aukauloo, Angew. Chem. Int. Ed. 2005, 44, 1536-1540.

a) C. Costentin, M. Robert, J.-M. Savéant, Acc. Chem. Res. 2010, 43, 1019-1029; b) C. Costentin, M. Robert, J. M. Savéant, J. Am. Chem. Soc. 2006, 128, 4552-4553; c) J. Bonin, C. Costentin, M. Robert, J. M. Savéant, Org. Biomol. Chem. 2011, 9, 4064-4069; d) C. Costentin, M. Robert, J. M. Savéant, C. Tard, Phys. Chem. Chem. Phys. 2011, 13, 5353-5358; e) J. Bonin, C. Costentin, C. Louault, M. Robert, M. Routier, J. M. Savéant, Proc. Natl. Acad. Sci. U. S. A. 2010, 107, 3367-3372; f) C. Costentin, M. Robert, J. M. Savéant, C. Tard, Angew. Chem. Int. Ed. 2010, 49, 3803-3806.

a) G. F. Moore, M. Hambourger, M. Gervaldo, O. G. Poluektov, T. Rajh, D. Gust, T. A. Moore, A. L. Moore, J. Am. Chem. Soc. 2008, 130, 10466-10467; b) S. Y. Reece, D. G. Nocera, J. Am. Chem. Soc 2005, 127, 9448-9458; c) I. J. Rhile, T. F. Markle, H. Nagao, A. G. DiPasquale, O. P. Lam, M. A. Lockwood, K. Rotter, J. M. Mayer, J. Am. Chem. Soc. 2006, 128, 6075-6088; d) I. J. Rhile, J. M. Mayer, J. Am. Chem. Soc. 2004, 126, 12718-12719; e) T. F. Markle, I. J. Rhile, A. G. DiPasquale, J. M. Mayer, Proc. Natl. Acad. Sci. U. S. A. 2008 , 105, 8185-8190; f) T. F. Markle, J. M. Mayer, Angew. Chem., Int. Ed 2008, 47, 738-740; g) A. Magnuson, M. Anderlund, O. Johansson, P. Lindblad, R. Lomoth, T. Polivka, S. Ott, K. Stensjö, S. Styring, V. Sundström, L. Hammarström, Acc. Chem. Res. 2009, 42, 18991909; h) O. Johansson, H. Wolpher, M. Borgström, L. Hammarström J. Bergquist, L. C. Sun, B. Åkermark, Chem. Commun. 2004, $194-$ 195; i) L. Hammarström, S. Styring, Energy Environ. Sci. 2011, 4, 2379-2388; j) A. Magnuson, H. Berglund, P. Korall, L. Hammarström, B. Åkermark, S. Styring, L. C. Sun, J. Am. Chem. Soc. 1997, 119, 10720-10725; k) M. Sjödin, T. Irebo, J. E. Utas, J. Lind, G. Merenyi, B. Åkermark, L. Hammarström, J. Am. Chem. Soc. 2006, 128 13076-13083; I) L. C. Sun, M. Burkitt, M. Tamm, M. K. Raymond, M. Abrahamsson, D. LeGourriérec, Y. Frapart, A. Magnuson, P. H. Kenéz, P. Brandt, A. Tran, L. Hammarström, S. Styring, B. Åkermark, J. Am. Chem. Soc. 1999, 121, 6834-6842; m) M.-T. Zhang, T. Irebo, O. Johansson, L. Hammarström, J. Am. Chem. Soc 2011, 133, 13224-13227; n) T. F. Markle, I. J. Rhile, J. M. Mayer, J. Am. Chem. Soc. 2011, 133, 17341-17352. Papanikolas, T. J. Meyer, Coord. Chem. Rev. 2010, 254, 24592471; b) O. S. Wenger, Chem.-Eur. J. 2011, 17, 11692-11702; c) T.
Irebo, S. Y. Reece, M. Sjödin, D. G. Nocera, L. Hammarström, J. Am. Chem. Soc. 2007, 129, 15462-15464; d) B. C. Westlake, M. K. Brennaman, J. J. Concepcion, J. J. Paul, S. E. Bettis, S. D. Hampton, S. A. Miller, N. V. Lebedeva, M. D. E. Forbes, A. M. Moran, T. J. Meyer, J. M. Papanikolas, Proc. Natl. Acad. Sci. U. S. A. 2011, 108, 8554-8558; e) T. I. A. Gerber, E. Hosten, P. Mayer, Z. R. Tshentu, J. Coord. Chem. 2006, 59, 243-253; f) J. F. Ireland, P. A. H. Wyatt, Adv. Phys. Org. Chem. 1976, 12, 131-160; g) C. Bronner, O. S. Wenger, J. Phys. Chem. Lett. 2012, 3, 70-74.

[7] W. B. Connick, A. J. Di Bilio, M. G. Hill, J. R. Winkler, H. B. Gray, Inorg. Chim. Acta 1995, 240, 169-173.

[8] T. Niwa, H. Yorimitsu, K. Oshima, Angew. Chem. Int. Ed. 2007, 46, 2643-2645.

[9] O. Mongin, P. Rocca, L. Thomas-dit-Dumont, F. Trécourt, F. Marsais, A. Godard, G. Quéguiner, J. Chem. Soc., Perkin Trans. 1 1995, 2503-2508.

[10] V. Diemer, H. Chaumeil, A. Defoin, A. Fort, A. Boeglin, C. Carré, Eur. J. Org. Chem. 2008, 1767-1776.

[11] a) T. Steiner, Angew. Chem. Int. Ed. 2002, 41, 48-76; b) X. M. Xiao, M.-A. Haga, T. Matsumurainoue, Y. Ru, A. W. Addison, K. Kano, J. Chem. Soc., Dalton Trans. 1993, 2477-2484; c) G. R. Desiraju, T. Steiner, The weak hydrogen bond, Oxford University Press, Oxford, 1999

[12] R. M. Silverstein, C. Bassler, T. C. Morrill, Spectrometric Identification of Organic Compounds, Vol. 5th edition, Wiley, New York, 1991

[13] F. G. Bordwell, J. P. Cheng, J. Am. Chem. Soc. 1991, 113, 17361743

[14] T. F. Markle, A. L. Tenderholt, J. M. Mayer, J. Phys. Chem. B 2012 116, 571-584.

[15] M. Yamaji, J. Oshima, M. Hidaka, Chem. Phys. Lett. 2009, 475, 235-239.

[16] V. V. Pavlishchuk, A. W. Addison, Inorg. Chim. Acta 2000, 298, 97102.

[17] I. Vedernikova, J. P. Tollenaere, A. Haemers, J. Phys. Org. Chem. 1999, 12, 144-150.

[18] V. W. Manner, T. F. Markle, J. H. Freudenthal, J. P. Roth, J. M. Mayer, Chem. Commun. 2008, 256-258.

[19] a) L. Sacksteder, A. P. Zipp, E. A. Brown, J. Streich, J. N. Demas, B A. DeGraff, Inorg. Chem. 1990, 29, 4335-4340; b) L. Wallace, D. P. Rillema, Inorg. Chem. 1993, 32, 3836-3843; c) K. S. Schanze, D. B. MacQueen, T. A. Perkins, L. A. Cabana, Coord. Chem. Rev. 1993, $122,63-89$

[20] J. A. Joule, K. Mills, Heterocyclic Chemistry, Vol. 3rd edition, Blackwell Science, Oxford, 2004

[21] P. K. Das, M. V. Encinas, J. C. Scaiano, J. Am. Chem. Soc. 1981 103, 4154-4162.

[22] M. E. Walther, O. S. Wenger, Dalton Trans. 2008, 6311-6318.

[23] D. M. Roundhill, Photochemistry and Photophysics of Metal Complexes, Plenum Press, New York, 1994.

[24] R. Lomoth, T. Haupl, O. Johansson, L. Hammarström, Chem.-Eur. J. 2002, 8, 102-110.

[25] T. A. Gadosy, D. Shukla, L. J. Johnston, J. Phys. Chem. A 1999, 103, 8834-8839.

[26] P. K. Das, M. V. Encinas, S. Steenken, J. C. Scaiano, J. Am. Chem. Soc. 1981, 103, 4162-4166.

[27] J. T. Kendall, J. Label. Compd. Radiopharm. 2000, 43, 917-924.

[28] T. Schulz, K. Meindl, D. Leusser, D. Stern, J. Graf, C. Michaelsen, M. Ruf, G. M. Sheldrick, D. Stalke, J. Appl. Crystallogr. 2009, 42, 885-891. 
[29] SAINT v7.68A; Bruker; WI, USA: Madison, 2009.

[30] Sheldrick, G. M. SADABS 2008/2; Göttingen, 2008.

[31] A. Vlcek, F. Bolletta, Inorg. Chim. Acta 1983, 76, L227-L229.

Received: ((will be filled in by the editorial staff))

Published online: ((will be filled in by the editorial staff))

[32] G. E. Adams, B. D. Michael, Trans. Faraday Soc. 1971, 67, 11711180 . 


\section{Entry for the Table of Contents}

Layout 1:

\section{ARTICLES}

Two pyridylphenols with intramolecular hydrogen bonds react with a metal complex via concerted proton-electron transfer: Upon photoexcitation of the complex, there is electron transfer from the phenol to the metal, and the phenolic proton is transferred to the pyridine moiety.

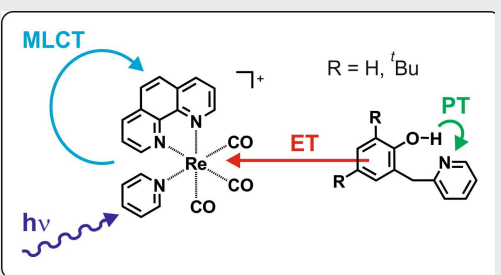

William Herzog, Catherine Bronner, Susanne Löffler, Bice He, Daniel Kratzert, Dietmar Stalke, Andreas Hauser, Oliver S. Wenger*

Page No. - Page No.

Electron Transfer between HydrogenBonded Pyridylphenols and a Photoexcited Rhenium(I) Complex 